\title{
Spatial and temporal patterns in Serranus cabrilla habitat use in the NW Mediterranean revealed by acoustic telemetry
}

\author{
Josep Alós ${ }^{1, *}$, David March ${ }^{1}$, Miquel Palmer ${ }^{1}$, Amalia Grau ${ }^{2}$, Beatriz Morales-Nin ${ }^{1}$ \\ ${ }^{1}$ Instituto Mediterráneo de Estudios Avanzados, IMEDEA (CSIC-UIB), C/ Miquel Marqués 21, 07190 Esporles, \\ Illes Balears, Spain \\ ${ }^{2}$ Laboratori d'Investigacions Marines i Aqüicultura (LIMIA), C/ Eng. Gabriel Roca 69, 07157 Port d'Andratx, \\ Illes Baleares, Spain
}

\begin{abstract}
We used acoustic telemetry to describe the spatial and temporal patterns of habitat use of one of the species most targeted by recreational anglers in the NW Mediterranean, Serranus cabrilla (Linnaeus, 1758). Temporal patterns and fish position were determined using a fixed-receiver array located in a marine protected area (MPA) in Palma Bay (Balearic Islands). Fish position as centre of activity (COA, the centre of the area the fish uses during a specific time) and space utilisation preferences could be described due to a receiver array design with a high range detection overlap (more densely distributed near the COA). There were significantly more detections per time unit during the day, which was interpreted as increased activity possibly related to feeding habits and social behaviour. $S$. cabrilla spent $95 \%$ of its time in an average area of $0.77 \pm 0.17 \mathrm{~km}^{2}$, with a core area ( $50 \%$ of the time) of $0.10 \pm 0.29 \mathrm{~km}^{2}$. The home range size was not related to fish size or diel pattern (i.e. the size of the daytime home range was not significantly different from the night range). The linearity index and the index of reuse (proxies of site fidelity) also demonstrated that this species has high site fidelity, which suggests that it is sedentary with a limited adult dispersal capacity. Two main habitats were observed in the study area, and $S$. cabrilla spent on average much less time in seagrass meadows (Posidonia oceanica beds) compared to soft, gravel and detritus bottoms. A relatively small MPA would be a useful management tool for establishing sustainable exploitation levels of this species.
\end{abstract}

KEY WORDS: Spatial-temporal patterns - Marine protected area $\cdot$ MPA · Recreational fishing · Simultaneous hermaphroditism $\cdot$ Acoustic telemetry $\cdot$ Serranus cabrilla

\section{INTRODUCTION}

The use of space is often not considered when population dynamics of exploited fish stocks are studied (Botsford et al. 2009). Although there has been some improvement (e.g. Pecl et al. 2006, Semmens et al. 2010), management decisions are traditionally made based on population-dynamics models that incorporate fishing effort and a number of biological traits, but assume fish populations to be spatially homogeneous (Botsford et al. 2009). This assumption is often unrealistic and can have significant practical implica- tions. Migration behaviour and movements of large migratory fish (e.g. bluefin tuna; Block et al. 2005) are very different from those of small reef species with a very limited home range (e.g. anemone fish; Fauntin 1991). These 2 examples represent extreme cases of space utilisation, and show that adequate knowledge of the spatial and temporal patterns of habitat use and fish movement would logically lead to a better understanding of fish population dynamics (Botsford et al. 2009).

One of the most obvious potential applications of information on spatial and temporal patterns of fish 
movement is in the design of marine protected areas (MPAs) (Botsford et al. 2003). The usefulness of MPAs is in relation to spillover and depends on the scale of fish movement in relation to the size of the MPA (Kramer \& Chapman 1999, Sale et al. 2005). To improve protection, MPAs must be large enough to enclose the appropriate habitats containing the regular movements of adult fish (i.e. their home range). Spillover of early life stages (usually with good dispersal capability) into areas outside the MPA can only happen if there is a sustainable adult population within the reserve (Kaplan et al. 2006). However, the extent of adult spillover also depends on cross-boundary movements (Kramer \& Chapman 1999, Bartholomew et al. 2008).

Spatial and temporal patterns of habitat use are also relevant for justifying the usefulness of some fish species as bio-indicators of anthropogenic impacts. Bio-indicator species should be sedentary in order to reflect local exposure to human impacts (Burger \& Gochfeld 2001). Moreover, fish abundance and behaviour can vary greatly at different temporal scales. The most obvious variations are those related to spawning aggregations (e.g. Begg \& Marteinsdottir 2002, Rowe \& Hutchings 2003, Berkeley et al. 2004, Lowerre-Barbieri et al. 2008, Walters et al. 2009, Semmens et al. 2010). However, more subtle variations operate over short time scales of hours to days (i.e. feeding or sheltering), and these can also affect fish abundance estimates and vulnerability to fishing pressure (Naylor 2005, Willis et al. 2006).

Fish acoustic telemetry is an alternative method to conventional tag-and-recapture studies of movement, and allows for understanding spatial and temporal scales but increases the cost and hence reduces the sample size that can be realised (e.g. Voegeli et al. 2001, Parsons \& Egli 2005). This technology can be used for example to (1) quantify home ranges within MPAs (e.g. Lowe et al. 2003, Parsons \& Egli 2005), (2) determine site fidelity (e.g. Collins et al. 2007, Abecasis \& Erzini 2008, Abecasis et al. 2009, Semmens et al. 2010) and (3) describe temporal patterns (e.g. diel activity) of marine fishes (e.g. Jadot et al. 2002, Jorgensen et al. 2006, March et al. 2010).

Determining the spatial and temporal patterns of habitat use is especially important when the species exploited is sedentary because fishing could lead to local depletion. This may be the case for the comber Serranus cabrilla (Osteichthyes, Serranidae). S. cabrilla is a simultaneous hermaphrodite that has a short lifespan and is associated with beds of the Mediterranean endemic macrophyte Posidonia oceanica and with sandy and muddy bottoms along the coasts of the eastern Atlantic Ocean and the Mediterranean Sea (Bauchot 1987). There are data available on age and growth (Tserpes \& Tsimenides 2001, Torcu-Koc et al. 2004), reproduction (Garcia-Diaz et al. 1997), feeding habits (Labropoulou \& Eleftheriou 1997) and also some behavioural aspects (Santos et al. 2002). However, spatial and temporal patterns of movement have not been previously reported.

This species is considered as by-catch and a lowvalue species by commercial fisheries in most regions of the NW Mediterranean. However, this species is one of those most frequently targeted by recreational fishing in this area (Morales-Nin et al. 2005, Lloret et al. 2008, Gordoa 2009). No specific management plan for Serranus cabrilla has ever been developed, probably due to its limited commercial interest. Additionally, this species has been shown to be vulnerable to the impact of recreational angling in terms of abundance and size (Ordines et al. 2005) and is considered to be an indicator of angling pressure (Harmelin 1987). The main purpose of the present study was to describe the spatial and temporal patterns of $S$. cabrilla movement using an omnidirectional receiver array. Specifically we described (1) temporal patterns and diel behaviour, (2) site fidelity, (3) home range area, and (4) habitat preferences in order to provide new biological information to facilitate future implementation of management plans to promote sustainable development of this fishery.

\section{MATERIALS AND METHODS}

Study site. The study was carried out in an MPA located in Palma Bay in the southern part of Mallorca Island (NW Mediterranean; Fig. 1) between May and October 2008. The Palma Bay MPA extends from the coastline to the $30 \mathrm{~m}$ isobath. Fishing activities have been regulated since 1982, albeit not enforced until the late 1990s (http://dgpesca.caib.es). There are 2 areas with different levels of protection: (1) the sanctuary area $\left(\sim 2 \mathrm{~km}^{2}\right)$, where only no-take activities are allowed, and (2) a buffer area where both artisanal and recreational fishing are regulated (Fig. 1). In the buffer area, temporal closures for some areas, minimum size and numbers of gears, bag and size limits and other management regulations are stipulated. A recent benthic cartography has been developed by the local government (Direcció General de Biodiversitat, Balearic Government) under the Posidonia-LIFE project framework, where 6 different habitat types were identified within the MPA boundaries (http://lifeposidonia. caib.es). The different habitat types in the area are: seagrass meadows (SM) dominated by the species Posidonia oceanica, photophyla algae (AL), sandy (FS) and gravel (GS) soft bottoms, a mixture of gravel and detritus (GD), and a mixture of algae and seagrasses 


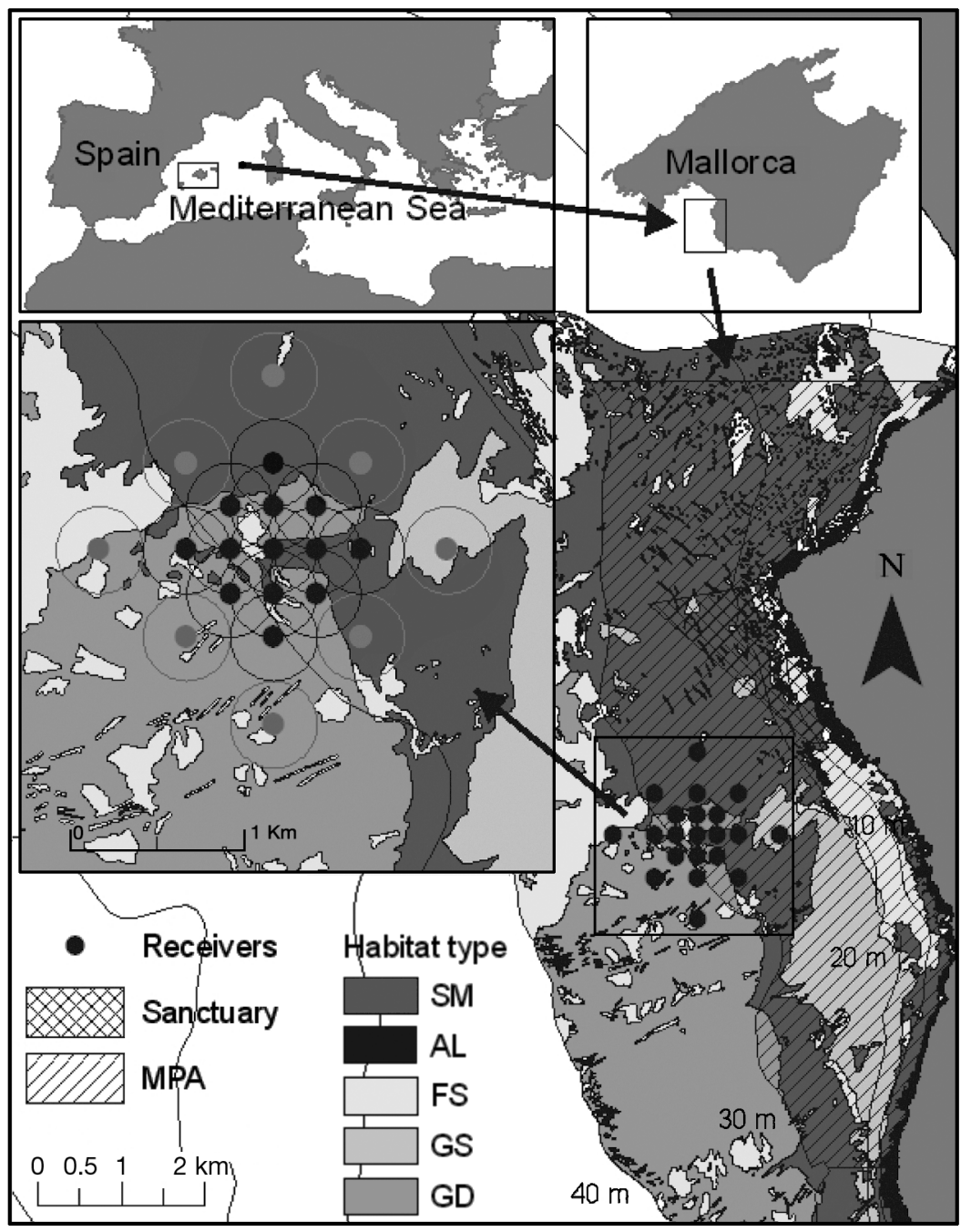

Fig. 1. Study site located in the marine protected area (MPA) of Palma Bay, Mallorca Island. Locations of the 2 fixed receiver arrays (- central area in which receivers were more densely located; $\bigcirc$ : peripheral area) and their buffer $(\sim 250 \mathrm{~m})$ areas are shown. SM: seagrass meadow; AL: algae; FS: fine sand; GS: gravel sand; GD: gravel and detritus

(AS) (Fig. 1). The area also includes a number of small artificial reefs $\left(\sim 1 \mathrm{~m}^{3}\right)$ that were randomly placed in 1989.

Experimental design. A fixed array of omnidirectional acoustic receivers (Sonotronics ${ }^{\circledR}$ SUR-1) was deployed to monitor the spatial and temporal movements of Serranus cabrilla in the south of the MPA (Fig. 1). The array was designed so that there was (1) a central area in which receivers were more densely located, and (2) a peripheral area. In the central area of the receiver array, 13 receivers were deployed at a distance of $250 \mathrm{~m}$ from each other (Fig. 1). This design allowed the detection range of each receiver to overlap with others, improving the accuracy of fish position estimates (Fig. 1). In the peripheral area, 8 more receivers were deployed, forming a $2 \times$ $2 \mathrm{~km}$ diamond surrounding the central array (Fig. 1). Thus, a total of 21 receivers were deployed, covering an area of approximately $2 \mathrm{~km}^{2}$ plus the detection range $(\sim 250 \mathrm{~m})$ of the receivers located in the peripheral area (Fig. 1). Each receiver was oriented upwards at 1 to $2 \mathrm{~m}$ from the bottom to optimise detection and avoid thermocline effects (March et al. 2010). After the tagging experiment and the expected battery life of the acoustic tags had expired, we retrieved the receivers and downloaded the data.

Sampling and tagging method. A total of 15 Serranus cabrilla individuals were acoustically tagged and released in the study site between the end of July and the beginning of September 2008 (Fig. 1, Table 1). During that period, most individuals tagged were in the post-spawning stage (GarciaDiaz et al. 1997). Most individuals ( $\mathrm{n}=$ 13) were tagged using acoustic Picotags PT-3 (Sonotronics ${ }^{\circledR}$ ). These electronic tags measured $19 \mathrm{~mm}$ in length and $7.8 \mathrm{~mm}$ in diameter, weighed $1 \mathrm{~g}$ in water and had an expected lifespan of $21 \mathrm{~d}$ when used continuously. However, they were customised to run intermittently to yield an active period of $12 \mathrm{~h} \mathrm{~d}^{-1}$; thus, the lifespan was increased to approximately $35 \mathrm{~d}$. In addition, one individual was tagged with the smallest version of Pico-tag (Sonotronics $^{\circledR}$ PT-1; size: $16 \times 7.1 \mathrm{~mm}$; weight in water: $0.6 \mathrm{~g}$; expected lifespan: $7 \mathrm{~d}$ ) and another one with another type of acoustic tag (Sonotronics ${ }^{\circledR}$ IBT96-1; size: $25 \times 8 \mathrm{~mm}$; weight in water: $1.5 \mathrm{~g}$; expected lifespan: $21 \mathrm{~d}$ ) (Table 1). These 2 additional acoustic tags were not customised.

The combination of a specific sequence of pulses at a specific frequency allowed fish to be identified (Table 1). Each time an omnidirectional acoustic receiver detected a signal (i.e. a specific pulse period range), it was recorded as a single detection, which was labelled with a detection number, date $(\mathrm{mm} / \mathrm{dd} /$ yy), hour (hh:mm:ss), frequency $(\mathrm{kHz})$ and interval period (ms). A tolerance interval of $5 \mathrm{~ms}$ was selected to remove false detections. Single detections made by a single transmitter over a period of $24 \mathrm{~h}$ were considered as spurious detections and also removed, following the decision criteria adopted by March et al. (2010). 
Table 1. Serranus cabrilla. Characteristics of the tagged fish and the tags. TL: total length; $\mathrm{TP}_{i}$ : period between release date and last detection; $\mathrm{DD}_{i}$ : total number of days detected; $\mathrm{RI}_{i}$ : residence index

\begin{tabular}{|c|c|c|c|c|c|c|c|c|c|c|c|}
\hline $\begin{array}{l}\text { Fish } \\
\text { code }\end{array}$ & $\begin{array}{c}\mathrm{TL} \\
(\mathrm{mm})\end{array}$ & $\begin{array}{l}\text { Weight } \\
\text { (g) }\end{array}$ & $\begin{array}{l}\text { Tag } \\
\text { model }\end{array}$ & $\begin{array}{l}\text { Tag frequency } \\
(\mathrm{kHz})\end{array}$ & $\begin{array}{c}\text { Tag interval } \\
(\mathrm{ms})\end{array}$ & $\begin{array}{l}\text { Release date } \\
\text { (dd/mm/yy) }\end{array}$ & $\begin{array}{c}\text { Total no. } \\
\text { of detections }\end{array}$ & $\begin{array}{l}\text { No. of } \\
\text { receivers }\end{array}$ & $\begin{array}{l}\mathrm{TP}_{i} \\
\text { (d) }\end{array}$ & $\begin{array}{l}\mathrm{DD}_{i} \\
\text { (d) }\end{array}$ & $\mathrm{RI}_{i}$ \\
\hline 1 & 151 & 53.4 & PT-3 & 69 & 870 & $18 / 07 / 08$ & 2211 & 10 & 61 & 55 & 0.90 \\
\hline 2 & 155 & 58.1 & PT-3 & 70 & 860 & 08/09/08 & 9 & 1 & 2 & 2 & 1.00 \\
\hline 4 & 154 & 57.3 & PT-3 & 72 & 880 & $18 / 07 / 08$ & 1850 & 7 & 25 & 25 & 1.00 \\
\hline 5 & 164 & 57.4 & PT-3 & 73 & 910 & $18 / 07 / 08$ & 1885 & 6 & 24 & 24 & 1.00 \\
\hline 6 & 140 & 49.2 & PT-3 & 74 & 900 & $18 / 07 / 08$ & 1650 & 7 & 16 & 16 & 1.00 \\
\hline 7 & 141 & 54.3 & PT-3 & 75 & 930 & 08/09/08 & 178 & 5 & 20 & 9 & 0.45 \\
\hline 8 & 122 & 37.6 & PT-1 & 76 & 920 & 09/07/08 & 808 & 7 & 4 & 4 & 1.00 \\
\hline 9 & 154 & 57.6 & PT-3 & 77 & 950 & 08/09/08 & 195 & 5 & 20 & 9 & 0.45 \\
\hline 10 & 168 & 61.3 & PT-3 & 78 & 940 & $21 / 08 / 08$ & 270 & 7 & 4 & 4 & 1.00 \\
\hline 17 & 154 & 57.9 & PT-3 & 70 & 1040 & $18 / 07 / 08$ & 775 & 8 & 11 & 11 & 1.00 \\
\hline 19 & 174 & 67.8 & PT-3 & 72 & 1060 & $21 / 08 / 08$ & 21 & 4 & 18 & 4 & 0.22 \\
\hline 20 & 168 & 60.7 & PT-3 & 73 & 1070 & $21 / 08 / 08$ & 218 & 4 & 38 & 20 & 0.53 \\
\hline 21 & 166 & 60.7 & PT-3 & 74 & 1080 & $21 / 08 / 08$ & 84 & 7 & 27 & 16 & 0.59 \\
\hline 80 & 163 & 60.4 & PT-3 & 76 & 920 & $18 / 07 / 08$ & 1150 & 4 & 12 & 12 & 1.00 \\
\hline 220 & 152 & 56.3 & IBT-96-1 & 78 & 1020 & $18 / 07 / 08$ & 7139 & 8 & 39 & 39 & 1.00 \\
\hline
\end{tabular}

Transmitters were activated a few minutes before being implanted in each individual.

All individuals were initially caught inside the fixed array by anglers. Large-sized hooks (size 4) and pieces of shrimp (Penaeus vannamei) were used as bait to reduce the incidence of deep-hooking (see details in Alós et al. 2008, 2009). Deep-hooking is one of the most important causes of post-release mortality in the genus Serranus (Alós 2008). Serranus species are prone to suffering barotraumas, which increases the mortality rate (Alós 2008). The effects of barotraumas were mitigated by using a 21-gauge hypodermic needle (length: 1.5 inches or $38 \mathrm{~mm}$ ) to extract the excess gas from the swim bladder, formed during rapid decompression (Alós 2008). Deep-hooked fish and fish with bleeding injuries or severe barotraumas (e.g. exophthalmia) were not tagged and released.

After capture, fish were measured (to the nearest $\mathrm{mm}$ ), weighed (to the nearest $\mathrm{mg}$ ), tagged with a conventional (external) T-bar (Floy Tags ${ }^{\circledR}$ ) and placed into an 801 onboard aerated fish-holding tank. Fish were anaesthetised by immersion in $10 \mathrm{l}$ filtered and sterile seawater with $100 \mathrm{mg} \mathrm{l}^{-1}$ of tricaine methanesulphonate (MS222). Each acoustic tag was surgically implanted into the peritoneal cavity, maximising sterile conditions. Acoustic tags never exceeded 1.5 to $2 \%$ of the fish's body weight. Different kinds of sutures (absorbable [Vicryl Rapide 5-0, Ethicon ${ }^{\circledR}$ ] as well as non-absorbable [Mersilk 4-0, Ethicon $\left.{ }^{\circledR}\right]$ ) and Dermabond, a topical skin adhesive (2-octyl cyanoacrilate, Ethicon $\left.{ }^{\circledR}\right)$, were first tested on dummy-tagged fish ( $\mathrm{n}=$ 6) in a laboratory experiment to test the behaviour of the fish and the cicatrisation of the incision. The results revealed normal behaviour 10 min after surgery and full cicatrisation in 2 wk using non-absorbable sutures (A. Grau \& J. Alós unpubl. data). The entire surgical process took $<5$ min. After the tag was implanted, the fish was released into another aerated onboard tank to recover until normal behaviour was observed (approx. 10 to $15 \mathrm{~min}$ ). Then fish were released at their capture sites within the fixed array of receivers following the protocol suggested by Jepsen et al. (2002). The GPS position, depth, day and hour of release were recorded for each tagged fish.

Data analysis. Temporal patterns: The number of days detected $\left(\mathrm{DD}_{i}\right)$ and the period between the release date and the last detection date (tracking period, $\mathrm{TP}_{i}$ ) of a specific tagged Fish $i$ were used to calculate a residence index $\left(\mathrm{RI}_{i}\right)$, defined as the quotient between $\mathrm{DD}_{i}$ and $\mathrm{TP}_{i}$ (Abecasis \& Erzini 2008, Abecasis et al. 2009, Semmens et al. 2010). Unlike Abecasis \& Erzini (2008), we estimated $\mathrm{RI}_{i}$ for each fish rather than for each receiver (March et al. 2010), and used this to determine the number of days that the fish was present in the fixed array (Collins et al. 2007).

Temporal sequences of detections were plotted as the number of detections per hour for each individual. Then we used continuous wavelet transform (CWT) to identified periodicity patterns in these time series. CWT is considered to be a useful tool for decomposing a time series into time-frequency space (Percival \& Walden 2000) and has been applied previously in acoustic tagging experiments (Subbey et al. 2008, March et al. 2010). The Morlet wavelet with the sowas package in $\mathrm{R}$ (version 2.11.0, R Foundation; www.rproject.org) was used to compute the 2-dimensional wavelet spectrum and calculate a point-wise test at a 
95\% significance level (Maraun et al. 2007). Wavelet coefficient values were normalised such that the highest spectral power equalled 1 (March et al. 2010).

Finally, we investigated diel patterns for each individual by pooling hourly detection data (i.e. number of detections per hour) into daily phases (day- vs. nighttime) and then comparing mean detections in each phase. Data from the US Naval Observatory (Astronomical Applications Department; http://aa.usno. navy.mil) was used to define each phase using sunrise and sunset to determine the day and night periods. Non-normal distribution of the data was detected and was not possible to transform adequately. Therefore we used a non-parametric Mann-Whitney $U$-test to test individually the hypothesis that the mean of number of detections was different between diel phases.

Spatial patterns: The Nadaraya-Watson kernel estimator (sm package in $\mathrm{R}_{i}$ Bowman \& Azzalini 1997) was used to calculate position estimates, or 'centre of activity' locations $\left(\mathrm{COA}_{i j}\right)$, for tracked fish $i$ for every 60 min period $j$ (see March et al. 2010. Thus, the estimation of the $\mathrm{XY}_{i j}$ position for Fish $i$ at Time $j$ was based on the positions of the receivers that detected the fish during the Period $j$ and weighted by the number of detections.

Two different methods were used to estimate the home range over the total period for each fish $i$ : (1) minimum convex polygons based on $100 \%$ of the positions $\left(\mathrm{MCP}_{i} 100\right) ;$ and (2) bivariate fixed-kernel utilisation distributions $\left(95 \%\right.$ and $\left.50 \% \mathrm{KUD}_{i}\right) . \mathrm{MCP}_{i}$ 100 provided information on the extent of an animal's home range over a given period, while KUD provided information on the use of space within a range including the core area $\left(50 \% \mathrm{KUD}_{i}\right)$ and the home range $\left(95 \% \mathrm{KUD}_{i}\right)$. These home-range estimations based on the COAs estimated for each fish were calculated over a grid with a $50 \times 50 \mathrm{~m}$ resolution using the adehabitat package in $\mathrm{R}$ (Calenge 2006). We selected a kernel bandwidth of $250 \mathrm{~m}$, which corresponded to the detection range of the acoustic tags used (see March et al. 2010). Pearson's correlation coefficient was used to determine whether the home range size was correlated either to fish size or the duration of $\mathrm{TP}_{i}$.

Changes in home range over time based on $95 \%$ $\mathrm{KUD}_{i}$ were also investigated. The cumulative 95\% $\mathrm{KUD}_{i}$ was expected to increase over time and to eventually arrive at an asymptotic value when a fish had explored most of its true home range (March et al. 2010). Thus, temporal changes in daily cumulative home range size were visually examined using home range curves. It was assumed that asymptotic 95\% KUD was reached when the difference in percentage between 2 consecutive days of the accumulated 95\% KUD was $<5 \%$ (Rechisky \& Wetherbee 2003). For each Fish $i$, the change in percentage for each tracked day was calculated as: \% change $=\left(\left[A_{\text {in }}-A_{\text {in-1 }}\right] / A_{\text {in }}\right) \times 100$, where $A_{i n}$ is the $95 \%$ KUD area on Day $n$ for Fish $i$, and $A_{\text {in-1 }}$ is the $95 \%$ KUD area on the previous day. Changes in the home range related to diel period were also investigated. Therefore, day and night $\mathrm{KUD}_{i} \mathrm{~S}$ were estimated on a daily basis for each fish. Nonnormal distribution of the data was detected, and a non-parametric Mann-Whitney $U$-test was used to test individually the hypothesis that the mean size of the home range $\left(50 \%\right.$ and $\left.95 \% \mathrm{KUD}_{i}\right)$ was different between diel phases.

The linearity index $\left(\mathrm{LI}_{i}\right)$ and the index of reuse $\left(\mathrm{IOR}_{i}\right.$ Rechisky \& Wetherbee 2003) were used as estimates of site fidelity and the direction of movements (random vs. directional movement; Danielson \& Swihart 1987). $\mathrm{LI}_{i}$ was calculated for each fish according to the formula $\mathrm{LI}_{i}=\left(F_{n}-F_{1}\right)_{i} / D_{i}$, where $F_{n}-F_{1}$ is the distance between the first and last $\mathrm{COA}_{i}$ for Fish $i$, and $D_{i}$ is the total distance travelled by that fish during the whole of $\mathrm{TP}_{i}$. Fish with nomadic behaviour showing directed movement are expected to have $\mathrm{LI}_{i}$ values close to 1 , while fish with high site fidelity and random movements at sites should have an $\mathrm{LI}_{i}$ value approaching 0 (Danielson \& Swihart 1987). IOR was estimated as $\mathrm{IOR}_{i n}=\left[\mathrm{OV}\left(A_{n}, A_{n+1}\right)_{i}\right] /\left[\mathrm{UN}\left(A_{n}, A_{n+1}\right)_{i}\right]$, where $\mathrm{OV}\left(A_{n}\right.$, $\left.A_{n+1}\right)_{i}$ is the area of overlap between 2 activity spaces (i.e. daily $50 \%$ or $95 \%$ KUD areas for Day $n$ and Day $n+1)$, and $\mathrm{UN}\left(A_{n}, A_{n+1}\right)_{i}$ is the area of union between the 2 activity spaces during $n$ days of the tracking period $\left(\mathrm{TP}_{i}\right)$ for Fish $i$. Values close to 1 for $\mathrm{IOR}_{i}$ denote high overlap of the activity spaces showing high site fidelity and discrete values of home range, while values close to 0 indicate non-overlap of activity space and nomadic spatial behaviour.

Finally, due to the heterogeneity of the bottom type in the study area, habitat use was investigated to determine the habitat preferences of Serranus cabrilla. However, considering the error of the $\mathrm{COA}_{i}$ estimations, we decided to only consider 2 main habitats: SM and soft and detritus bottoms (SDB). The habitat selection index $\left(\mathrm{HSI}_{i}\right)$ was used to estimate preference or avoidance of the available habitat type within the home range (Topping et al. 2005). $\mathrm{HSI}_{i}$ was estimated as the quotient between habitat utilisation, defined as the percentage of estimated positions $\left(\mathrm{COA}_{i}\right)$ in a specific habitat for Fish $i$, and the habitat availability, as a percentage of each bottom type in the estimated $\mathrm{MCP}_{i} 100$ during the tracking period for each fish (Topping et al. 2005). Thus, preference or avoidance was estimated according to the degree of deviation in a positive or negative direction from a value of 1 (Topping et al. 2005). HSI $_{i}$ was also estimated for each habitat during the day and night for each tagged fish (i.e. HSI $_{i}$ values were estimated for each fish). 


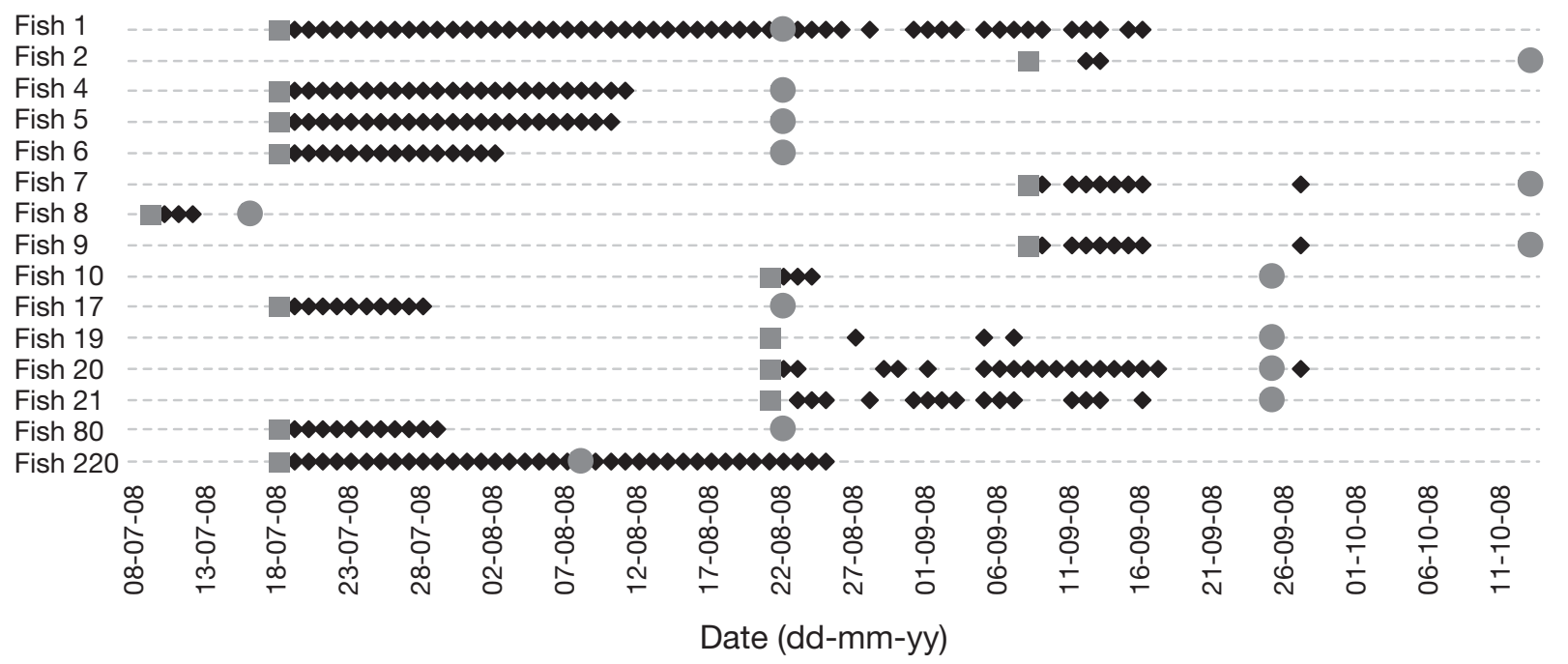

Fig. 2. Serranus cabrilla. Daily absence-presence plots of tagged fish within the monitored area between the first release date and the last expected transmission date. Days on which detections were made $(\bullet)$, transmitter deployment dates $(\square)$ and expected transmitter death dates $(\odot)$ are shown

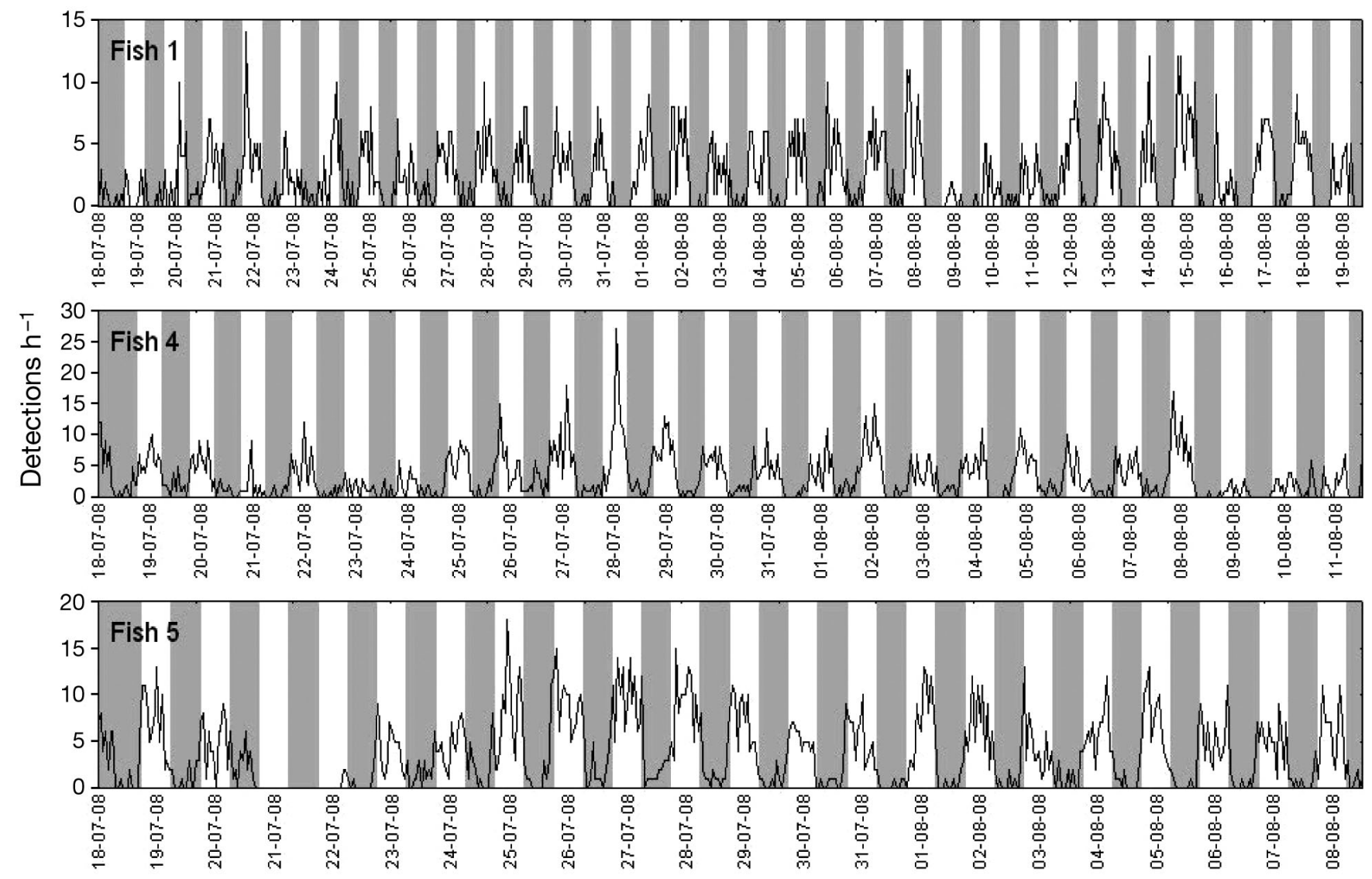

Fig. 3. Serranus cabrilla. Time series of the number of detections per hour per day of Fishes 1 (upper panel), 4 (middle panel) and 5 (lower panel). Vertical stripes represent day (white) and night (grey). Note the periodicity of the detection patterns related to day and night, with a higher number of detections during the day 


\section{RESULTS}

The characteristics of the Serranus cabrilla individuals tagged and of the acoustic tags are summarised in Table 1. A total of 18443 detections were downloaded from the array of receivers with a minimum of 9 detections (Fish 2) and a maximum of 7139 (Fish 220), and an average $( \pm \mathrm{SD})$ of $1230 \pm 1806$ detections (Table 1 ). The number of receivers that detected a certain tagged fish varied from 1 (Fish 2) to a maximum of 10 (Fish 1), with an average of $6 \pm 2.2$ receivers (Table 1 ).

Three individuals (Fishes 2, 8 and 10) were monitored on $<10 \mathrm{~d}$ and thus were not considered in our analysis of temporal and spatial patterns due the limited monitored period (i.e. sample size) (Table 1). For the other fish, $\mathrm{TP}_{i}$ varied from $11 \mathrm{~d}$ (Fish 17) to $61 \mathrm{~d}$ (Fish 1), with an average of $25.9 \pm 14.2 \mathrm{~d}$ (Table 1$). \mathrm{DD}_{i}$ varied from $2 \mathrm{~d}$ (Fish 2) to $55 \mathrm{~d}$ (Fish 1), with an average of $16.7 \pm 14.6 \mathrm{~d}$ (Table 1$). \mathrm{RI}_{i}$ ranged from 0.22 to 1 , with an average of $0.79 \pm 0.27$. However, for more than half of the fish $(\mathrm{n}=8), \mathrm{RI}_{i}$ was 1 , indicating that these fish were in the monitored area on a daily basis. Most $(80 \%)$ of the total tagged fish showed an $\mathrm{RI}_{i}$ value $>0.5$ (Table 1). Fig. 2 shows a time series of the daily absence-presence of tagged Serranus cabrilla in the monitored area.

\section{Temporal patterns}

Visual inspection of the hourly detections showed a clear temporal pattern characterised by a higher number of detections during the day than during the night (Fig. 3). The $24 \mathrm{~h}$ periodicity of these temporal patterns was also clearly observed by fitting CWT decomposition to the time series into time-frequency space. Fig. 4 shows the wavelet spectrograms of 8 individuals for which significant patches were observed in the $24 \mathrm{~h}$ scale, indicating a daily periodicity in the detections. These $24 \mathrm{~h}$ periodicities extended over several days for Fishes 1, 4, 5, 17, 80 and 220 (Fig. 4). In other cases, the periodicities were not as clear, but significant patches
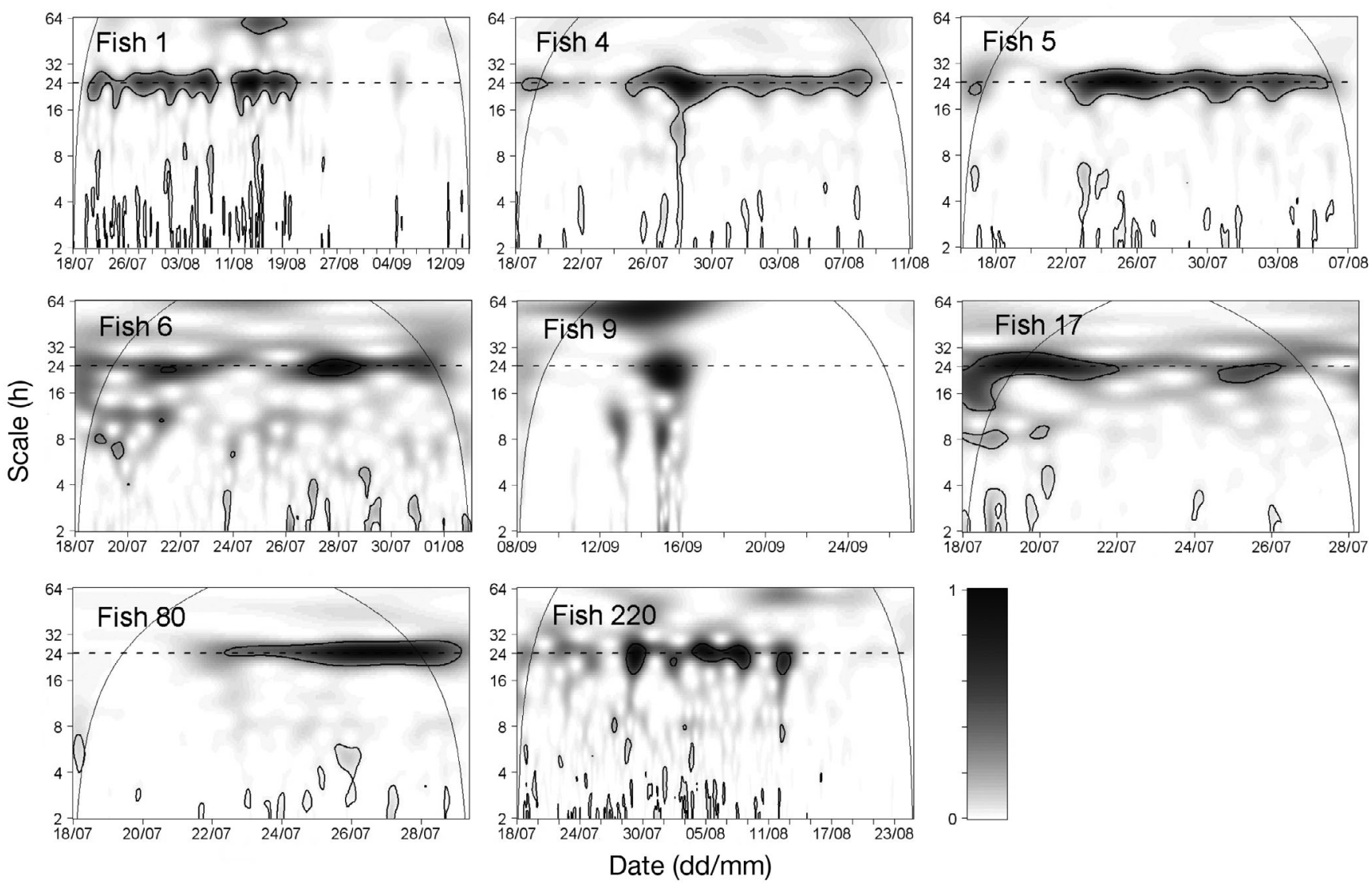

Fig. 4. Serranus cabrilla. Wavelet sample spectrums using a Morlet wavelet for 8 tagged fish (Fishes 1, 4, 5, 6, 9, 17, 80 and 220). Periodicities were detected in all cases on a $24 \mathrm{~h}$ scale (horizontal dashed line). Continuous thin lines represent the cone of influence (COI). Values outside the COI should not be interpreted due to edge effects. Thick contours represent the $95 \%$ confidence level and scale bar represents the intensity of the time-frequency space over time 
for short periods were also observed in Fishes 6 and 9 (Fig. 4). All individuals showed a mean detection per hour that was significantly higher during the day compared to the night (Mann-Whitney $U$-test; Table 2). Differences between means were greater when the number of detections was larger (Table 2).

Table 2. Serranus cabrilla. Total and mean number of hourly detections in the day- and night-time obtained for each fish tagged. For all fish tagged, the mean difference between diel phases was significant (Mann Whitney $U$-test: $\mathrm{p}<0.001$ )

\begin{tabular}{|c|c|c|c|}
\hline \multirow{2}{*}{$\begin{array}{l}\text { Fish } \\
\text { code }\end{array}$} & \multirow[t]{2}{*}{ Diel phase } & \multicolumn{2}{|c|}{$\longrightarrow$ No. of detections -} \\
\hline & & Total & Mean \pm SD \\
\hline \multirow[t]{2}{*}{1} & Day & 1893 & $2.44 \pm 2.61$ \\
\hline & Night & 318 & $0.47 \pm 1.12$ \\
\hline \multirow[t]{2}{*}{4} & Day & 1564 & $4.55 \pm 3.72$ \\
\hline & Night & 286 & $1.17 \pm 1.54$ \\
\hline \multirow[t]{2}{*}{5} & Day & 1620 & $4.91 \pm 3.89$ \\
\hline & Night & 265 & $1.13 \pm 1.76$ \\
\hline \multirow[t]{2}{*}{6} & Day & 1163 & $5.33 \pm 3.56$ \\
\hline & Night & 487 & $3.16 \pm 2.7$ \\
\hline \multirow[t]{2}{*}{7} & Day & 136 & $1.03 \pm 1.93$ \\
\hline & Night & 42 & $0.33 \pm 0.96$ \\
\hline \multirow[t]{2}{*}{9} & Day & 153 & $1.22 \pm 2.3$ \\
\hline & Night & 42 & $0.33 \pm 0.93$ \\
\hline \multirow[t]{2}{*}{17} & Day & 662 & $4.47 \pm 3.77$ \\
\hline & Night & 113 & $1.09 \pm 2.24$ \\
\hline \multirow[t]{2}{*}{19} & Day & 18 & $0.08 \pm 0.36$ \\
\hline & Night & 3 & $0.01 \pm 0.15$ \\
\hline \multirow[t]{2}{*}{20} & Day & 188 & $0.55 \pm 1.16$ \\
\hline & Night & 30 & $0.09 \pm 0.4$ \\
\hline \multirow[t]{2}{*}{21} & Day & 76 & $0.22 \pm 0.74$ \\
\hline & Night & 8 & $0.02 \pm 0.15$ \\
\hline \multirow[t]{2}{*}{80} & Day & 905 & $5.59 \pm 3.99$ \\
\hline & Night & 245 & $2.15 \pm 2.69$ \\
\hline \multirow[t]{2}{*}{220} & Day & 4808 & $9.37 \pm 6.11$ \\
\hline & Night & 2331 & $5.67 \pm 4.58$ \\
\hline
\end{tabular}

\section{Spatial patterns}

The number of $\mathrm{COA}_{i}$ locations varied from 29 (Fish 19) to 952 (Fish 1), with an average of $331.4 \pm$ 294.3 COAs. $\mathrm{MCP}_{i} 100$ varied from $0.035 \mathrm{~km}^{2}$ (Fish 220 ) to $0.438 \mathrm{~km}^{2}$ (Fish 21) and had an average of $0.21 \pm 0.12 \mathrm{~km}^{2}$. Pearson's correlation index showed that $\mathrm{MCP}_{i} 100$ values were not correlated with $\mathrm{TP}_{i}(\mathrm{p}=$ $0.70)$ or fish size $(p=0.84)$.

Home range derived from $95 \% \mathrm{KUD}_{i}$ s varied from 0.44 to $1.2 \mathrm{~km}^{2}$, with an average of $0.77 \pm 0.17 \mathrm{~km}^{2}$ (Table 3). In the case of $50 \% \mathrm{KUD}_{i} \mathrm{~s}$ (core area), areas ranged from 0.10 to $0.29 \mathrm{~km}^{2}$, with an average of $0.18 \pm$ $0.05 \mathrm{~km}^{2}$ (Table 3). Estimated $\mathrm{KUD}_{i} \mathrm{~s}$ did not show a significant relationship with either $\mathrm{TP}_{i}\left(95 \% \mathrm{KUD}_{i} \mathrm{~s}: \mathrm{p}\right.$ $\left.=0.123 ; 50 \% \mathrm{KUD}_{i} \mathrm{~s}: \mathrm{p}=0.121\right)$ or fish size $(95 \%$ $\left.\mathrm{KUD}_{i} \mathrm{~s}: \mathrm{p}=0.504 ; 50 \% \mathrm{KUD}_{i} \mathrm{~s}: \mathrm{p}=0.935\right)$. Fig. 5 shows the estimated $\mathrm{MCP}_{i} 100,95 \% \mathrm{KUD}_{i} \mathrm{~s}$ and $50 \% \mathrm{KUD}_{i} \mathrm{~s}$ for Fishes 1, 6, 7, 9, 20 and 220.

The plots of changes in the daily cumulative values of $95 \% \mathrm{KUD}_{i}$ for visual inspections of the temporal patterns of space utilisation are shown in Fig. 6. Based on the $95 \% \mathrm{KUD}_{i}$ values, we can see that most fish $(\mathrm{n}=9)$ stabilised their home range during the tracking period (Fig. 6). The tracking days when the cumulative home range reached a constant value (i.e. percentage of daily change $<5 \%$ ) are shown in Table 3. Fish 20 showed a step on tracking Day 22, but then the cumulative percentage remained constant (Fig. 6). However, Fishes 17, 19 and 80 increased their home ranges without reaching an asymptote (Fig. 6). In these cases, the daily cumulative area was characterised by a number of steps at different times. Fish 17 showed a large step on tracking Day 6, Fish 19 showed one on Day 7, and Fish 80 on Day 10 (Fig. 6).

Table 3. Serranus cabrilla. Asymptote (i.e. day on which the accumulated home range changed $<5 \%$ ), minimum convex polygons based on $100 \%$ of the positions $\left(\mathrm{MCP}_{i} 100\right)$ and bivariate normal fixed-kernel utilisation distributions $(50 \%$ and $95 \%$ KUD $)$ estimated for each fish. The $\mathrm{p}$-value shown corresponds to the significance of the Mann-Whitney $U$ test carried out to compare means in diel patterns and mean home ranges. nd: home range did not reach an asymptote; ns: not significant

\begin{tabular}{|c|c|c|c|c|c|c|c|c|c|c|}
\hline \multirow{2}{*}{$\begin{array}{l}\text { Fish } \\
\text { code }\end{array}$} & \multirow{2}{*}{$\begin{array}{l}\text { Asymptote } \\
\text { (d) }\end{array}$} & \multirow{2}{*}{$\begin{array}{l}\mathrm{MCP}_{i} 100 \\
\left(\mathrm{~km}^{2}\right)\end{array}$} & \multicolumn{4}{|c|}{$-50 \% \mathrm{KUD}_{i}\left(\mathrm{~km}^{2}\right)$} & \multirow[b]{2}{*}{ Total } & \multicolumn{2}{|c|}{$95 \% \mathrm{KUD}_{i}\left(\mathrm{~km}^{2}\right)$} & \multirow[b]{2}{*}{$\mathrm{p}$} \\
\hline & & & Total & $\begin{array}{c}\text { Day } \\
\text { (mean } \pm \mathrm{SD})\end{array}$ & $\begin{array}{c}\text { Night } \\
(\text { mean } \pm \text { SD) }\end{array}$ & $\mathrm{p}$ & & $\begin{array}{c}\text { Day } \\
\text { (mean } \pm \mathrm{SD})\end{array}$ & $\begin{array}{c}\text { Night } \\
(\text { mean } \pm \text { SD) }\end{array}$ & \\
\hline 1 & 2 & 0.375 & 0.13 & $0.12 \pm 0.04$ & $0.12 \pm 0.03$ & ns & 0.66 & $0.52 \pm 0.13$ & $0.51 \pm 0.10$ & ns \\
\hline 4 & 3 & 0.237 & 0.18 & $0.13 \pm 0.02$ & $0.16 \pm 0.04$ & $<0.001$ & 0.78 & $0.54 \pm 0.06$ & $0.68 \pm 0.14$ & $<0.001$ \\
\hline 5 & 9 & 0.188 & 0.15 & $0.11 \pm 0.01$ & $0.16 \pm 0.04$ & $<0.001$ & 0.74 & $0.51 \pm 0.07$ & $0.65 \pm 0.14$ & $<0.001$ \\
\hline 6 & 7 & 0.206 & 0.22 & $0.11 \pm 0.02$ & $0.12 \pm 0.04$ & ns & 0.83 & $0.49 \pm 0.09$ & $0.52 \pm 0.14$ & ns \\
\hline 7 & 3 & 0.188 & 0.14 & $0.13 \pm 0.03$ & $0.12 \pm 0.02$ & ns & 0.69 & $0.54 \pm 0.08$ & $0.51 \pm 0.09$ & ns \\
\hline 9 & 8 & 0.188 & 0.15 & $0.12 \pm 0.02$ & $0.12 \pm 0.03$ & $\mathrm{~ns}$ & 0.75 & $0.50 \pm 0.06$ & $0.50 \pm 0.10$ & ns \\
\hline 17 & nd & 0.396 & 0.14 & $0.11 \pm 0.01$ & $0.15 \pm 0.05$ & $<0.05$ & 0.81 & $0.48 \pm 0.05$ & $0.60 \pm 0.16$ & ns \\
\hline 19 & nd & 0.125 & 0.21 & $0.11 \pm 0.01$ & $0.10 \pm 0.00$ & ns & 0.85 & $0.45 \pm 0.06$ & $0.44 \pm 0.02$ & ns \\
\hline 20 & 23 & 0.062 & 0.15 & $0.10 \pm 0.01$ & $0.10 \pm 0.00$ & ns & 0.62 & $0.44 \pm 0.04$ & $0.43 \pm 0.02$ & ns \\
\hline 21 & 9 & 0.438 & 0.29 & $0.11 \pm 0.03$ & $0.10 \pm 0.00$ & ns & 1.20 & $0.47 \pm 0.09$ & $0.42 \pm 0.00$ & ns \\
\hline 80 & nd & 0.063 & 0.18 & $0.10 \pm 0.00$ & $0.11 \pm 0.03$ & ns & 0.77 & $0.43 \pm 0.01$ & $0.46 \pm 0.09$ & ns \\
\hline 220 & 2 & 0.035 & 0.10 & $0.11 \pm 0.01$ & $0.09 \pm 0.01$ & $<0.001$ & 0.44 & $0.44 \pm 0.01$ & $0.43 \pm 0.01$ & $<0.001$ \\
\hline
\end{tabular}



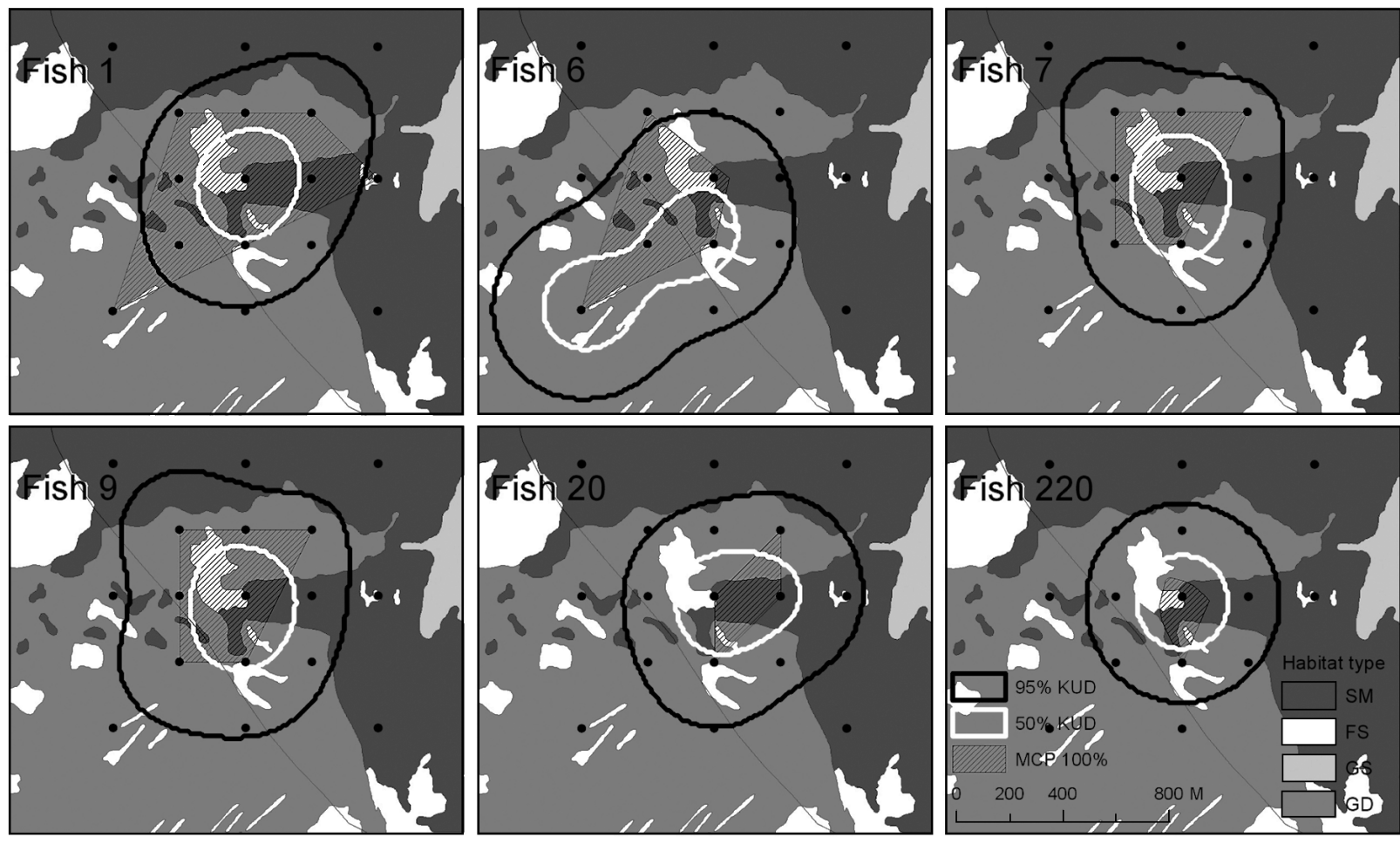

Fig. 5. Serranus cabrilla. Plots of space utilisation estimated for 6 tagged fish (Fishes 1, 6, 7, 9, 20 and 220). The graphical representation shows the minimum convex polygons based on $100 \%$ of the positions $\left(\mathrm{MCP}_{i} 100\right)$ and the bivariate fixed-kernel utilisation distributions $\left(50 \%\right.$ and $\left.95 \% \mathrm{KUD}_{i}\right)$ estimated according to the information from the receiver array (•: fixed receivers). SM: seagrass meadow; FS: fine sand; GS: gravel sand; GD: gravel and detritus
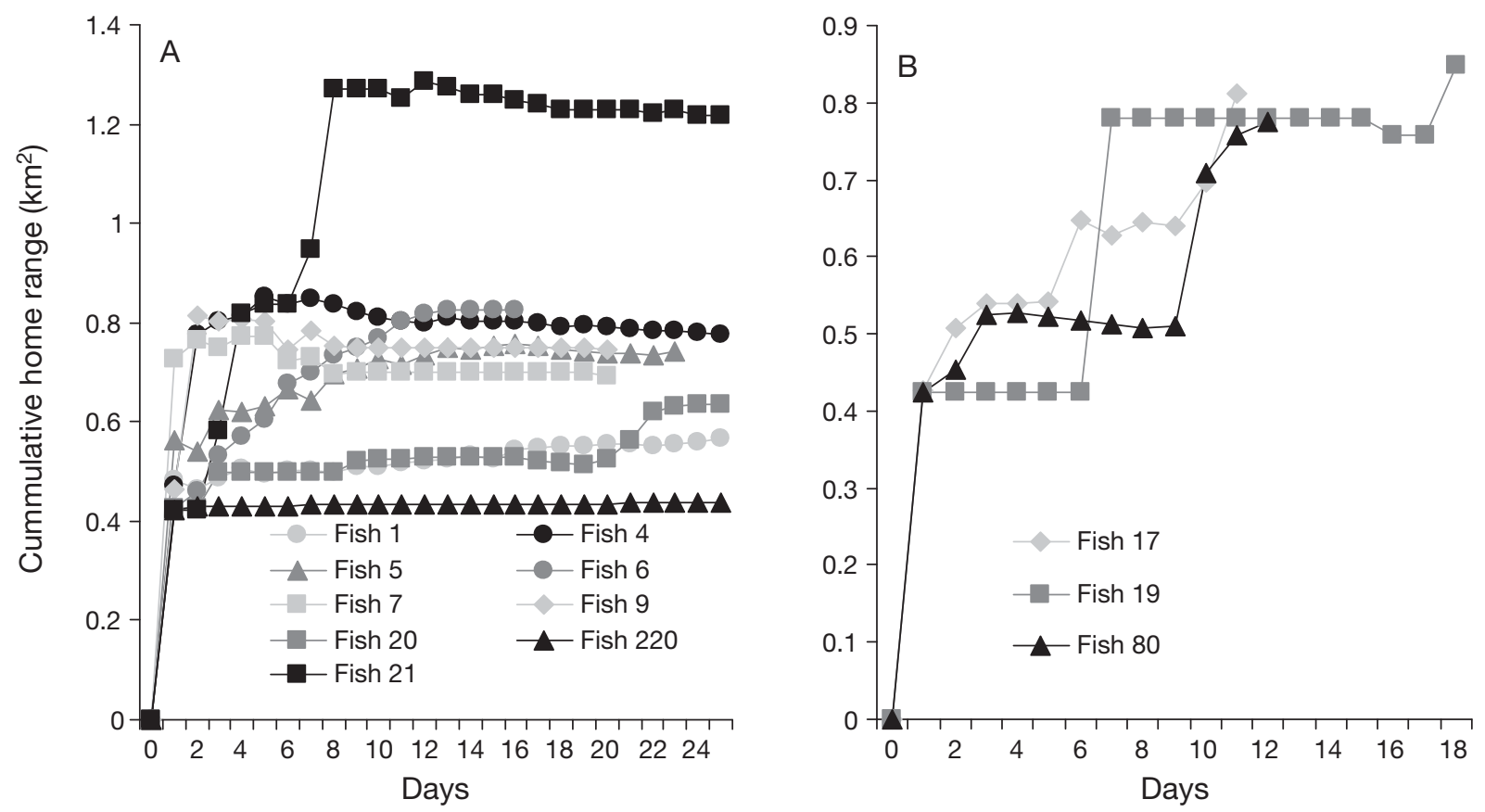

Fig. 6. Serranus cabrilla. Daily cumulative home range estimates (based on the bivariate fixed-kernel utilisation distribution for the home range $\left[95 \% \mathrm{KUD}_{i}\right]$ ) for tagged fish. Individuals whose home range (A) eventually reached an asymptote, indicating that the activity space increased little with additional tracking time (the time series was limited to $25 \mathrm{~d}$ to improve visualisation), and (B) did not reach an asymptote 
Most fish did not show significant differences in the mean daily home range estimated for day and night (Table 3). Fishes 4, 5 and 220 had significantly higher mean home range sizes during the night compared to

Table 4. Serranus cabrilla. Total time and total distance tracked for each tagged fish, as well as individual values of the linearity index $\left(\mathrm{LI}_{i}\right)$ and mean values of the index of reuse $\left(\mathrm{IOR}_{i}\right)$ based on the bivariate normal fixed-kernel utilisation distributions $\left(50 \%\right.$ and $\left.95 \% \mathrm{KUD}_{i}\right)$

\begin{tabular}{|rrrlcc|}
\hline $\begin{array}{c}\text { Fish } \\
\text { code }\end{array}$ & $\begin{array}{c}\mathrm{Time}_{i} \\
(\mathrm{~h})\end{array}$ & $\begin{array}{c}\text { Distance } \\
(\mathrm{m})\end{array}$ & $\mathrm{LI}_{i}$ & $\begin{array}{c}\mathrm{IOR}_{50 i} \\
(\mathrm{mean} \pm \mathrm{SD})\end{array}$ & $\begin{array}{c}\mathrm{IOR}_{95 i} \\
(\mathrm{mean} \pm \mathrm{SD})\end{array}$ \\
\hline 1 & 1442 & 73189.51 & 0.001 & $0.53 \pm 0.27$ & $0.67 \pm 0.21$ \\
4 & 581 & 67823.61 & 0.01 & $0.27 \pm 0.23$ & $0.60 \pm 0.15$ \\
5 & 540 & 46475.74 & 0.01 & $0.44 \pm 0.26$ & $0.61 \pm 0.15$ \\
6 & 361 & 25727.48 & 0.03 & $0.60 \pm 0.26$ & $0.75 \pm 0.19$ \\
7 & 463 & 7310.83 & 0.04 & $0.48 \pm 0.32$ & $0.69 \pm 0.22$ \\
9 & 460 & 5473.17 & 0.05 & $0.46 \pm 0.34$ & $0.66 \pm 0.23$ \\
17 & 246 & 17515.72 & 0.03 & $0.47 \pm 0.24$ & $0.63 \pm 0.17$ \\
19 & 411 & 1867.59 & 0.25 & $0.31 \pm 0.44$ & $0.51 \pm 0.37$ \\
20 & 894 & 4685.48 & 0.01 & $0.65 \pm 0.38$ & $0.78 \pm 0.23$ \\
21 & 1251 & 10421.82 & 0.03 & $0.23 \pm 0.33$ & $0.36 \pm 0.33$ \\
80 & 273 & 5625.03 & 0.13 & $0.77 \pm 0.23$ & $0.87 \pm 0.15$ \\
220 & 908 & 20775.49 & 0.001 & $0.82 \pm 0.11$ & $0.91 \pm 0.06$ \\
\hline
\end{tabular}

Table 5. Serranus cabrilla. Percentage of available habitats (based on the minimum convex polygons that are based on $100 \%$ of the positions $\left.\left[\mathrm{MCP}_{i} 100\right]\right)$, percentages of estimated centres of activity $\left(\mathrm{COA}_{i} \mathrm{~s}\right)$ related to diel phase per habitat, and habitat selection index $\left(\mathrm{HSI}_{i}\right)$ related to diel phase for each tagged fish. SM: seagrass meadow; SDB: soft and detritus bottoms

\begin{tabular}{|cccrrrrr|}
\hline \multirow{2}{*}{$\begin{array}{c}\text { Fish } \\
\text { code }\end{array}$} & \multirow{2}{*}{ Habitat } & \multirow{2}{*}{$\begin{array}{l}\text { Habitat } \\
\text { area (\%) }\end{array}$} & \multicolumn{2}{c}{ COA $_{i}(\%)$} & \multicolumn{2}{c|}{ HSI $_{i}$} \\
& & & Night & Day & Night \\
\hline \multirow{2}{*}{1} & SDB & 74.36 & 70.67 & 93.14 & 0.95 & 1.25 \\
& SM & 25.64 & 29.33 & 6.86 & 1.14 & 0.27 \\
4 & SDB & 86.70 & 97.35 & 99.03 & 1.12 & 1.14 \\
& SM & 13.30 & 2.65 & 0.97 & 0.20 & 0.07 \\
5 & SDB & 87.89 & 80.82 & 92.97 & 0.92 & 1.06 \\
& SM & 12.11 & 19.18 & 7.03 & 1.58 & 0.58 \\
6 & SDB & 86.12 & 89.42 & 97.87 & 1.04 & 1.14 \\
& SM & 13.88 & 10.58 & 2.13 & 0.76 & 0.15 \\
7 & SDB & 81.59 & 95.71 & 91.67 & 1.17 & 1.12 \\
& SM & 18.41 & 4.29 & 8.33 & 0.23 & 0.45 \\
9 & SDB & 81.59 & 94.03 & 96.30 & 1.15 & 1.18 \\
& SM & 18.41 & 5.97 & 3.70 & 0.32 & 0.20 \\
17 & SDB & 86.93 & 70.92 & 90.28 & 0.82 & 1.04 \\
& SM & 13.07 & 29.08 & 9.72 & 2.22 & 0.74 \\
19 & SDB & 87.15 & 100.00 & 100.00 & 1.15 & 1.15 \\
& SM & 12.85 & 0.00 & 0.00 & 0.00 & 0.00 \\
20 & SDB & 45.96 & 59.30 & 91.43 & 1.29 & 1.99 \\
& SM & 54.04 & 40.70 & 8.57 & 0.75 & 0.16 \\
21 & SDB & 90.34 & 98.91 & 100.00 & 1.09 & 1.11 \\
& SM & 9.66 & 1.09 & 0.00 & 0.11 & 0.00 \\
80 & SDB & 81.81 & 99.38 & 98.17 & 1.21 & 1.20 \\
& SM & 18.19 & 0.62 & 1.83 & 0.03 & 0.10 \\
220 & SDB & 44.27 & 70.78 & 92.95 & 1.60 & 2.10 \\
& SM & 55.73 & 29.22 & 7.05 & 0.52 & 0.13 \\
& & & & & & \\
\hline
\end{tabular}

during the day, both in 50\% KUD and 95\% KUD (Table 3). Fish 17 also had significant higher mean home range sizes during the night compared to during the day (Table 3). However, the home range of this individual did not reach an asymptote (Fig. 6).

$\mathrm{LI}_{i}$ and $\mathrm{IOR}_{i}$ for all tagged fish are summarised in Table 4 . The first index varied less and ranged from 0.001 (Fishes 1 and 220) to 0.25 (Fish 19), with an average of $0.05 \pm 0.07$ (Table 4). The highest values $(0.25$ and 0.13 ; Table 5) correspond to Fishes 19 and 80 respectively, which did not reach an asymptotic value for the cumulative home range (Fig. 6). The mean of $\mathrm{IOR}_{i}$ estimated on a daily basis varied from $0.23 \pm 0.33$ (Fish 21) to $0.82 \pm 0.11$ (Fish 220) for the estimations based on $50 \%$ KUD, while values based on $95 \%$ KUD varied from $0.36 \pm 0.33$ (Fish 21) to $0.91 \pm 0.06$ (Fish 220) (Table 4).

Habitat use within the area defined by $\mathrm{MCP}_{i}$ 100 varied between fish (Table 5). The 2 habitat categories SM and SDB were observed to have an average availability of $22.1 \pm 15.9 \%$ and $77.9 \pm 15.9 \%$, respectively (Table 5). Both during the day and at night, the percentage of $\mathrm{COA}_{i} \mathrm{~s}$ that were on SDB habitat was higher than the percentage in SM habitat (Table 5, Fig. 7). Table 5 shows that day and night $\mathrm{HSI}_{i}$ values varied among fish. The higher values correspond to SDB both during the day (1.13 \pm $0.2)$ and at night $(1.29 \pm 0.36)$ (Table 5). The lower values, both during the day $(0.66 \pm 0.69)$ and at night $(0.24 \pm 0.0 .23)$, were observed in SM (Table 5). Fig. 7 shows the mean and SD of the percentages of $\mathrm{COA}_{i} \mathrm{~s}$ and $\mathrm{HSI}_{i}$ related to habitat type.

\section{DISCUSSION}

The usefulness of omnidirectional receiver arrays for monitoring fish behaviour has been extensively described (Heupel et al. 2006). In the present study, the combination of a receiver array and miniaturised acoustic tags provided new information on the spatial and temporal behaviour of Serranus cabrilla, one of the most important recreational target species in the NW Mediterranean Sea. A diel pattern has been clearly demonstrated in $S$. cabrilla. Santos et al. (2002) found that this species and another 2 similarly sized species from the same genus, $S$. scriba and $S$. hepatus, were more frequently observed in a visual census during the day than at night. A previ- 


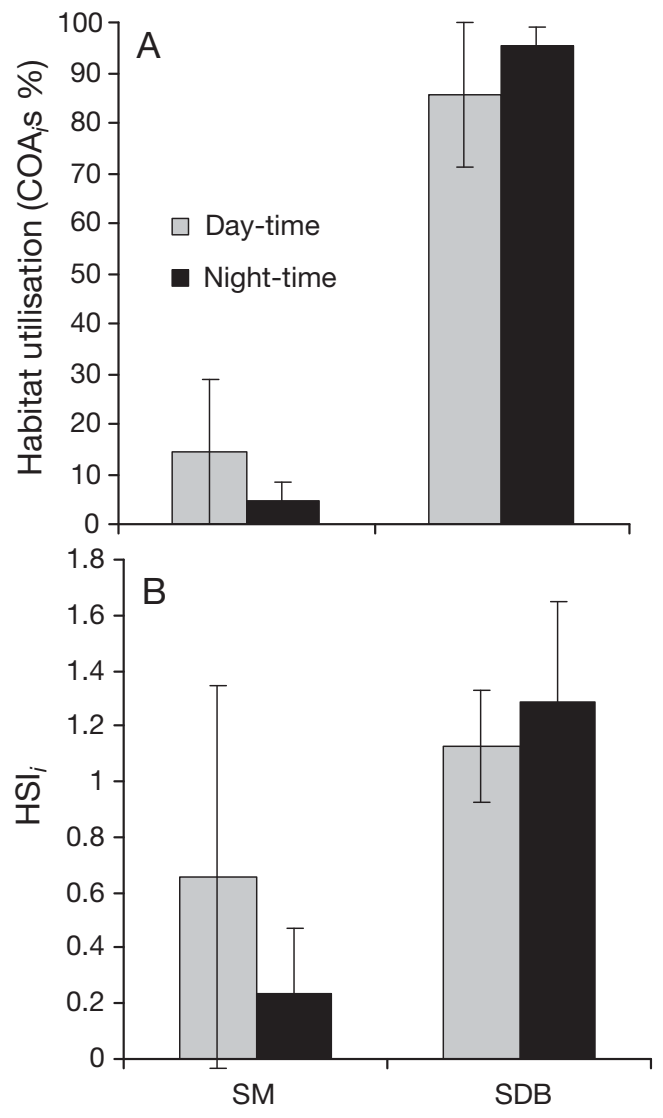

Fig. 7. Serranus cabrilla. (A) Mean percentage of centres of activity $\left(\mathrm{COA}_{i} \mathrm{~s}\right)$ and $(\mathrm{B})$ mean values for habitat selection index $\left(\mathrm{HSI}_{i}\right)$ related to habitat type and diel phase. SM: seagrass meadow; SDB: soft and detritus bottoms. Error bars represent SD

ous study using passive telemetry showed diel patterns for S. scriba, which suggests a sheltering behaviour during the night within the seagrass meadow (March et al. 2010).

Although our results were clear (the chronogram of almost all the fish showed a clear increase in detections per hour during the day), the increase in detections in relation to activity patterns is a controversial issue. On the one hand, authors such as Topping et al. (2005) suggested that there is a negative relationship between detection frequency and movement rate, because the probability of being detected by a receiver is higher when fish are less mobile. On the other hand, Zeller (1997) and March et al. (2010) proposed that a higher number of detections during the day is due to the increased probability of fish being detected in their more active periods. In other cases, diel patterns were caused by changes in habitat use (e.g. Jadot et al. 2002, 2006, Verweij \& Nagelkerken 2007 ) or were due to tidal variations (e.g. Humston et al. 2005).
In the case of Serranus cabrilla in the present study, there was no relationship between diel pattern and home-range size. Thus, the observed diel patterns appeared to be caused by the decrease in activity and mobility during the night. During the day, S. cabrilla was more active, and the probability of a fish being detected increased, probably due to feeding habits and social behaviour. During the night, fish were less mobile, less visible and remained hidden, which decreased the probability of being detected. This kind of diel behaviour has been reported for other temperate-reef fish and attributed to predation avoidance during the night (e.g. Chateau \& Wantiez 2007, March et al. 2010).

The position estimation obtained by acousticreceiver arrays can be improved using an array design in which the detection ranges of more than one receiver overlap (Simpfendorfer et al. 2002, 2008, Hedger et al. 2008). In the present study, the array design used allowed us to estimate a large number of COAs for most of the fish and then estimate homerange areas and habitat preferences. To estimate COAs, we obtained $\mathrm{MCP}_{i} 100$ for each tagged fish, which averaged $0.21 \pm 0.12 \mathrm{~km}^{2} . \mathrm{MCP}_{i} 100$ tends to be inaccurate due to the large weight of a few extreme COA estimates (March et al. 2010). However, even taking this into account, the $\mathrm{MCP}_{i} 100$ results gave evidence to support the sedentary nature and high site fidelity of Serranus cabrilla.

Bivariate fixed-kernel utilisation distributions seem to be more robust against outlier COAs (March et al. 2010). The present study results showed that Serranus cabrilla spends $95 \%$ of its time within an average area of $0.77 \pm 0.17 \mathrm{~km}^{2}$, and its core area ( $50 \%$ of the time) is $0.10 \pm 0.29 \mathrm{~km}^{2}$. These results agree with observations previously reported that describe this species as sedentary with a limited adult dispersal capability (Harmelin 1987). Other smaller-sized serranids of the same genus also have small home-range sizes (S. scriba: $95 \%$ KUD: 0.76 to $1.3 \mathrm{~km}^{2}$; core area: 0.17 to $0.29 \mathrm{~km}^{2}$; March et al. 2010). However, larger-sized serranids seem to have smaller home ranges: e.g. Plectropomus leopardus (0.1 to $0.2 \mathrm{~km}^{2}$; Zeller 1997), Epinephelus guttatus (112 to $5636 \mathrm{~m}^{2}$; Shapiro et al. 1994), Paralabrax clathratus $\left(33 \mathrm{~m}^{2}\right.$ to $0.01 \mathrm{~km}^{2}$; Lowe et al. 2003) and E. tauvina (0.07 to $0.73 \mathrm{~km}^{2}$; Kaunda-Arara \& Rose 2004). The relationship with bottom features on a microhabitat scale in small-sized serranids is not as clear as in large-sized species (La Mesa et al. 2002). It is interesting to note that the large serranids with small home ranges mentioned just above are all protogynous hermaphrodites, and in most cases they are socially structured in harems where the largest male protects a group of females from other males. In contrast, the 2 small-sized species of genus Serranus ( $S$. cabrilla and S. scriba) are simultaneous hermaphrodites, and the 
social and reproductive behaviour of this strategy is often complex and unknown in most cases (Petersen 2006).

The present results showed that the home-range size was uncorrelated with fish size. This disagrees with the results obtained for larger-sized serranids, which are protogynous hermaphrodites and sex-changing fish (Kaunda-Arara \& Rose 2004). For example, in Epinephelus tauvina, the larger individuals (males) show smaller home ranges than the smaller individuals (immature fish, females and young/smaller males; Kaunda-Arara \& Rose 2004). However, our results agree with those reported for Serranus scriba, which are also simultaneous hermaphrodites (March et al. 2010).

For the relationship between space utilisation and diel patterns, our results showed that most of the fish had home-range areas that did not significantly change between day and night. Serranus scriba shows the same pattern (March et al. 2010). However, other species show different space use during day and night (e.g. Lowry \& Suthers 1998, Jadot et al. 2002, 2006, Verweij \& Nagelkerken 2007). In S. cabrilla, although fish were detected less frequently by the receivers, fish used the same-sized space and the same location. The results agree with the conclusion mentioned above, that the observed diel patterns appeared to be caused by the decrease in activity and mobility during the night.

Our results demonstrate that Serranus cabrilla has high site fidelity. On the one hand, $\mathrm{LI}_{i}$ values were usually close to 0 (mean \pm SD: $0.05 \pm 0.07$ ), which suggests that $\mathrm{LI}_{i}$ values are more related to random movements at the site than directed movement (Danielson \& Swihart 1987). On the other hand, $\mathrm{IOR}_{i}$ mean values on a daily basis showed high overlap in activity spaces on 2 consecutive days. In fact, $91.6 \%$ of the tagged fish showed a mean $\mathrm{IOR}_{i}$ value $>0.5$ (i.e. tagged fish used $>50 \%$ of the same activity spaces on 2 consecutive days). Another small serranid (S. scriba) also shows high site fidelity (March et al. 2010). Thus, all results reported here support the conclusion that $S$. cabrilla is a sedentary species with a limited adult dispersal capability and higher activity during the day than at night.

Our results confirmed that the habitat of Serranus cabrilla begins at the edge of the seagrass meadow (Posidonia oceanica beds). Therefore, this species does not have the same habitat preferences as $S$. scriba, which predominantly inhabits seagrass meadows (Moranta et al. 2006, Deudero et al. 2008, March et al. 2010). In the present study, S. cabrilla was found to inhabit soft bottoms with rocks and detrital habitats more frequently. However, it is interesting to note that seagrass meadows could play a role in the life history of $S$. cabrilla, either as adult individuals or in early life stages, and this opens up new paradigms for further research.
The movement patterns of Serranus cabrilla (one of the main targets of the recreational fishery in the western Mediterranean) need to be taken into account in MPA design. Temporal and spatial distribution of fish movement patterns needs to be incorporated into models of protected fish populations (Botsford et al. 2009). To achieve conservation and fisheries management goals, MPAs have to be of sufficient size to protect the target species (Kramer \& Chapman 1999). S. cabrilla is sedentary, with a home-range size frequently $<1 \mathrm{~km}^{2}$. Thus, a relatively small MPA could significantly reduce fishing mortality of fish located within the protected area. This has 2 main implications to the whole of the fishery. First, if the population is allowed to increase in density inside the MPA, more adult individuals are likely to be closer to the boundary and exposed to fishing mortality beyond the protected area (Kramer \& Chapman 1999). Second, a relatively small MPA could maintain a number of old and large fish which are known to have higher fecundity. This pool of high-fecundity fish could be the key to maintaining sustainable population levels in exploited surrounding areas via spillover of eggs and larvae (i.e. because these early life stages are pelagic). This species has been catalogued as a bio-indicator of fishing pressure (Harmelin 1987) and it is vulnerable to angling and overexploitation (Ordines et al. 2005); therefore, it is expected that it would respond well to protection.

Acknowledgements. We thank the staff of the Direcció General de Pesca (Govern de les Illes Balears) and the researchers who helped with the experimental fishing and logistic procedures, especially A. Beltrán and M. Cabanellas. This study was financed by the research project CONFLICT (CGL200800958) funded by the Spanish Ministry of Science and Innovation. The habitat map was obtained from the LIFE-Posidonia program (Govern de les Illes Balears). J.A. and D.M. were supported by an FPI fellowship (MICINN).

\section{LITERATURE CITED}

Abecasis D, Erzini K (2008) Site fidelity and movements of gilthead sea bream (Sparus aurata) in a coastal lagoon (Ria Formosa, Portugal). Estuar Coast Shelf Sci 79:758-763

Abecasis D, Bentes L, Erzini K (2009) Home range, residency and movements of Diplodus sargus and Diplodus vulgaris in a coastal lagoon: connectivity between nursery and adult habitats. Estuar Coast Shelf Sci 85:525-529

Alós J (2008) Influence of anatomical hooking depth, capture depth, and venting on mortality of painted comber (Serranus scriba) released by recreational anglers. ICES J Mar Sci 65:1620-1625

Alós J, Palmer M, Grau AM, Deudero S (2008) Effects of hook size and barbless hooks on hooking injury, catch per unit effort, and fish size in a mixed-species recreational fishery in the western Mediterranean Sea. ICES J Mar Sci 65: 899-905

Alós J, Arlinghaus R, Palmer M, March D, Álvarez I (2009) The influence of type of natural bait on fish catches and hooking location in a mixed-species marine recreational 
fishery, with implications for management. Fish Res 97: 270-277

Bartholomew A, Bohnsack JA, Smith SG, Ault JS, Harper DE, McClellan DB (2008) Influence of marine reserve size and boundary length on the initial response of exploited reef fishes in the Florida Keys National Marine Sanctuary, USA. Landscape Ecol 23(Suppl 1):55-65

Bauchot ML (1987) Serranidae. In: Fischer W, Bauchot ML, Schneider $M$ (eds) Fiches FAO d'indentification des espèces pour les besoins de la pêche (Révision 1), Méditerranée et Mer Noire. Zones de pechê 37, Vol II (Vertébrés). FAO, Rome, p 1301-1319. Available at: ftp:// ftp.fao.org/docrep/fao/009/x0170f/X0170F00.pdf

- Begg GA, Marteinsdottir G (2000) Spawning origins of pelagic juvenile cod Gadus morhua inferred from spatially explicit age distributions: potential influences on yearclass strength and recruitment. Mar Ecol Prog Ser 202: 193-217

Berkeley SA, Hixon MA, Larson RL, Love MS (2004) Fisheries sustainability via protection of age structure and spatial distribution of fish population. Fisheries (Bethesda) 29: 23-32

Block BA, Teo SLH, Walli A, Boustany A and others (2005) Electronic tagging and population structure of Atlantic bluefin tuna. Nature 434:1121-1127

Botsford LW, Micheli F, Hastings A (2003) Principles for the design of marine reserves. Ecol Appl 13(Suppl):25-31

Botsford LW, Brumbaugh DR, Grimes C, Kellner JB and others (2009) Connectivity, sustainability, and yield: bridging the gap between conventional fisheries management and marine protected areas. Rev Fish Biol Fish 19:69-95

Bowman A, Azzalini A (1997) Applied smoothing techniques for data analysis: the kernel approach with S-Plus illustrations. Oxford University Press, Oxford

Burger J, Gochfeld M (2001) On developing bioindicators for human and ecological health. Environ Monit Assess 66: 23-46

Calenge C (2006) The package 'adehabitat' for the R software: a tool for the analysis of space and habitat use by animals. Ecol Modell 197:516-519

$>$ Chateau O, Wantiez L (2007) Site fidelity and activity patterns of a humphead wrasse, Cheilinus undulatus (Labridae), as determined by acoustic telemetry. Environ Biol Fishes 80: 503-508

Collins AB, Heupel MR, Motta PJ (2007) Residence and movement patterns of cownose rays Rhinoptera bonasus within a south-west Florida estuary. J Fish Biol 71: 1159-1178

Danielson BJ, Swihart RK (1987) Home range dynamics and activity patterns of Microtus ochrogaster and Synaptomys cooperi in syntopy. J Mammal 68:160-165

Deudero S, Morey G, Frau A, Moranta J, Moreno I (2008) Temporal trends of littoral fishes at deep Posidonia oceanica seagrass meadows in a temperate coastal zone. J Mar Syst 70:182-195

Fauntin DG (1991) The anemonefish symbiosis: what is known and what is not. Symbiosis 10:23-46

Garcia-Diaz MM, Tuset VM, Gonzalez JA, Socorro J (1997) Sex and reproductive aspects in Serranus cabrilla (Osteichthyes: Serranidae): macroscopic and histological approaches. Mar Biol 127:379-386

Gordoa A (2009) Characterization of the infralittoral system along the north-east Spanish coast based on sport shorebased fishing tournament catches. Estuar Coast Shelf Sci 82:41-49

> Harmelin JG (1987) Structure and variability of the ichthyofauna in a Mediterranean protected rocky area (National
Park of Port Cros, France). PSZN I: Mar Ecol 8:263-284

> Hedger RD, Martin F, Dodson JJ, Hatin D, Caron F, Whoriskey FG (2008) The optimized interpolation of fish positions and speeds in an array of fixed acoustic receivers. ICES J Mar Sci 65:1248-1259

> Heupel MR, Semmens JM, Hobday AJ (2006) Automated acoustic tracking of aquatic animals: scales, design and deployment of listening station arrays. Mar Freshw Res 57:1-13

Humston R, Ault JS, Larkin MF, Luo JG (2005) Movements and site fidelity of the bonefish Albula vulpes in the northern Florida Keys determined by acoustic telemetry. Mar Ecol Prog Ser 291:237-248

> Jadot C, Ovidio M, Voss J (2002) Diel activity of Sarpa salpa (Sparidae) by ultrasonic telemetry in a Posidonia oceanica meadow of Corsica (Mediterranean Sea). Aquat Living Resour 15:343-350

> Jadot C, Donnay A, Acolas ML, Cornet Y, Anras MLB (2006) Activity patterns, home-range size, and habitat utilization of Sarpa salpa (Teleostei: Sparidae) in the Mediterranean Sea. ICES J Mar Sci 63:128-139

> Jepsen N, Koed A, Thorstad EB, Baras E (2002) Surgical implantation of telemetry transmitters in fish: how much have we learned? Hydrobiologia 483:239-248

> Jorgensen SJ, Kaplan DM, Klimley AP, Morgan SG, O'Farrell MR, Botsford LW (2006) Limited movement in blue rockfish Sebastes mystinus: internal structure of home range. Mar Ecol Prog Ser 327:157-170

> Kaplan DM, Botsford LW, Jorgensen S (2006) Dispersal per recruit: an efficient method for assessing sustainability in marine reserve networks. Ecol Appl 16:2248-2263

Kaunda-Arara B, Rose GA (2004) Homing and site fidelity in the greasy grouper Epinephelus tauvina (Serranidae) within a marine protected area in coastal Kenya. Mar Ecol Prog Ser 277:245-251

> Kramer DL, Chapman MR (1999) Implications of fish home range size and relocation for marine reserve function. Environ Biol Fishes 55:65-79

> La Mesa G, Louisy P, Vacchi M (2002) Assessment of microhabitat preferences in juvenile dusky grouper (Epinephelus marginatus) by visual sampling. Mar Biol 140: 175-185

> Labropoulou M, Eleftheriou A (1997) The foraging ecology of two pairs of congeneric demersal fish species: importance of morphological characteristics in prey selection. J Fish Biol 50:324-340

> Lloret J, Zaragoza N, Caballero D, Riera V (2008) Biological and socioeconomic implications of recreational boat fishing for the management of fishery resources in the marine reserve of Cap de Creus (NW Mediterranean). Fish Res 91:252-259

Lowe CG, Topping DT, Cartamil DP, Papastamatiou YP (2003) Movement patterns, home range, and habitat utilization of adult kelp bass Paralabrax clathratus in a temperate notake marine reserve. Mar Ecol Prog Ser 256:205-216

Lowerre-Barbieri SK, Barbieri LR, Flanders JR, Woodward AG, Cotton CF, Knowlton MK (2008) Use of passive acoustics to determine red drum spawning in Georgia waters. Trans Am Fish Soc 137:562-575

Lowry MB, Suthers IM (1998) Home range, activity and distribution patterns of a temperate rocky-reef fish, Cheilodactylus fuscus. Mar Biol 132:569-578

> Maraun D, Kurths J, Holschneider M (2007) Nonstationary Gaussian processes in wavelet domain: synthesis, estimation, and significance testing. Phys Rev E 75:016707

> March D, Palmer M, Alós J, Grau A, Cardona F (2010) Shortterm residence, home range size and diel patterns of the 
painted comber Serranus scriba in a temperate marine reserve. Mar Ecol Prog Ser 400:195-206

Morales-Nin B, Moranta J, Garcia C, Tugores MP, Grau AM, Riera F, Cerda M (2005) The recreational fishery off Majorca Island (western Mediterranean): some implications for coastal resource management. ICES J Mar Sci 62:727-739

Moranta J, Palmer M, Morey G, Ruiz A, Morales-Nin B (2006) Multi-scale spatial variability in fish assemblages associated with Posidonia oceanica meadows in the western Mediterranean Sea. Estuar Coast Shelf Sci 68:579-592

Naylor E (2005) Chronobiology: implications for marine resource exploitation and management. Sci Mar 69 (Suppl 1):157-167

Ordines F, Moranta J, Palmer M, Lerycke A, Suau A, MoralesNin B, Grau AM (2005) Variations in a shallow rocky reef fish community at different spatial scales in the western Mediterranean Sea. Mar Ecol Prog Ser 304:221-233

Parsons D, Egli D (2005) Fish movement in a temperate marine reserve: new insights through application of acoustic tracking. Mar Technol Soc J 39:56-63

Pecl GT, Tracey SR, Semmens JM, Jackson GD (2006) Use of acoustic telemetry for spatial management of southern calamary Sepioteuthis australis, a highly mobile inshore squid species. Mar Ecol Prog Ser 328:1-15

Percival D, Walden A (2000) Wavelet methods for time series analysis. Cambridge University Press, Cambridge

> Petersen CW (2006) Sexual selection and reproductive success in hermaphroditic seabasses. Integr Comp Biol 46: 439-448

Rechisky EL, Wetherbee BM (2003) Short-term movements of juvenile and neonate sandbar sharks, Carcharhinus plumbeus, on their nursery grounds in Delaware Bay. Environ Biol Fishes 68:113-128

Rowe S, Hutchings JA (2003) Mating systems and the conservation of commercially exploited marine fish. Trends Ecol Evol 18:567-572

Sale PF, Cowen RK, Danilowicz BS, Jones GP and others (2005) Critical science gaps impede use of no-take fishery reserves. Trends Ecol Evol 20:74-80

Santos MN, Monteiro CC, Gaspar MB (2002) Diurnal variations in the fish assemblage at an artificial reef. ICES J Mar Sci 59(Suppl):S32-S35

Semmens JM, Buxton CD, Forbes E, Phelan MJ (2010) Spatial and temporal use of spawning aggregation sites by the tropical sciaenid Protonibea diacanthus. Mar Ecol Prog Ser 403:193-203

Shapiro DY, Garcia-Moliner G, Sadovy Y (1994) Social system of inshore stock of the red hind grouper, Epinephelus guttatus (Pisces, Serranidae). Environ Biol Fishes 41:415-422

Simpfendorfer CA, Heupel MR, Hueter RE (2002) Estimation of short-term centers of activity from an array of omnidirectional hydrophones and its use in studying animal movements. Can J Fish Aquat Sci 59:23-32

Simpfendorfer CA, Heupel MR, Collins AB (2008) Variation in the performance of acoustic receivers and its implication for positioning algorithms in a riverine setting. Can J Fish Aquat Sci 65:482-492

Subbey S, Michalsen K, Nilsen GK (2008) A tool for analyzing information from data storage tags: the continuous wavelet transform (CWT). Rev Fish Biol Fish 18:301-312

Topping DT, Lowe CG, Caselle JE (2005) Home range and habitat utilization of adult California sheephead, Semicossyphus pulcher (Labridae), in a temperate no-take marine reserve. Mar Biol 147:301-311

Torcu-Koc H, Turker-Cakir D, Dulcic J (2004) Age, growth and mortality of the comber, Serranus cabrilla (Serranidae) in the Edremit Bay (NW Aegean Sea, Turkey). Cybium 28:19-25

Tserpes G, Tsimenides N (2001) Age, growth and mortality of Serranus cabrilla (Linnaeus, 1758) on the Cretan shelf. Fish Res 51:27-34

Verweij MC, Nagelkerken I (2007) Short and long-term movement and site fidelity of juvenile Haemulidae in back-reef habitats of a Caribbean embayment. Hydrobiologia 592:257-270

Voegeli FA, Smale MJ, Webber DM, Andrade Y, O'Dor RK (2001) Ultrasonic telemetry, tracking and automated monitoring technology for sharks. Environ Biol Fishes 60: $267-281$

Walters S, Lowerre-Barbieri S, Bickford J, Mann D (2009) Using a passive acoustic survey to identify spotted seatrout spawning sites and associated habitat in Tampa Bay, Florida. Trans Am Fish Soc 138:88-98

Willis TJ, Badalamenti F, Milazzo M (2006) Diel variability in counts of reef fishes and its implications for monitoring. J Exp Mar Biol Ecol 331:108-120

> Zeller DC (1997) Home range and activity patterns of the coral trout Plectropomus leopardus (Serranidae). Mar Ecol Prog Ser 154:65-77

Submitted: May 6, 2010; Accepted: January 17, 2011

Proofs received from author(s): March 21, 2011
Editorial responsibility: Hans Heinrich Janssen, Oldendorf/Luhe, Germany 